\title{
Carl Schmitt o państwie jako monopolu polityczności (a nie przemocy) ${ }^{1}$
}

DOI 10.35757/CIV.2015.17.08

Carl Schmitt, coraz lepiej znany w Polsce teoretyk polityki i prawa, wciąż postrzegany jest nie tyle jako twórca koncepcji polityczności, ile jej apologeta, zwolennik stale obecnego podziału na przyjaciół i wrogów, krwawej walki i wojny, w myśl którego nie ma miejsca na pokój, stabilność ani bezpieczeństwo, tak jakby owe wartości były dla niego zupełnie nieistotne.

Takie odczytanie autora Pojęcia polityczności jako zwolennika przemocy jest w mojej ocenie błędne, gdyż nie bierze pod uwagę prostego i wydawałoby się oczywistego faktu, że Schmitt był prawnikiem, a więc, jeśli można tak powiedzieć, reprezentował pewien, wynikający $z$ wykształcenia, stosowanej metody i doświadczenia, typ umysłowości, dla którego prawo pozytywne, legalność, państwo, a co za tym idzie - także stabilność, pewność i bezpieczeństwo, sa istotnymi wartościami i nawet jeśli wykraczał poza wasski horyzont myślenia prawniczego, to czynił tak nie jako filozof, politolog, socjolog ani tym bardziej ideolog, lecz wciąż jako prawnik. To w byciu prawnikiem należy widzieć naturalna skłonność do zachowywania (a nie do rewolucji i burzenia), a także, jakże

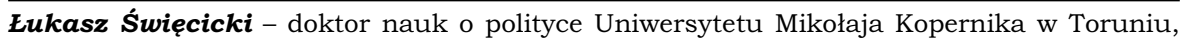
doktorant $\mathrm{w}$ dyscyplinie nauki o bezpieczeństwie na Uniwersytecie Przyrodniczo-Humanistycznym w Siedlcach.

1 Artykuł został sfinansowany z grantu Ministerstwa Nauki i Szkolnictwa Wyższego nr DI201 016141. 
istotne przecież $z$ uwagi na dyskusję o jego dziele, źródło jego oportunizmu w czasach rząów hitlerowskich.

Schmitt był prawnikiem wyrosłym $z$ wilhelmińskiej tradycji nauki prawa, w której dominowali pozytywiści prawniczy. Szybko wystapił przeciwko tej tradycji, wchodzac $z$ nia $w$ intrygujacca i wciąż warta zainteresowania intelektualna polemikę, w której $z$ pomoca przyszła mu między innymi znana $z$ seminariów, na które uczęszczał w Monachium, teoria Maksa Webera. Weber, którego nie chciałbym $w$ tym miejscu utożsamiać ani $z$ pozytywizmem prawnym (jak chciałby tego Leo Strauss), ani $z$ opozycja wobec tego nurtu, pozwolił Schmittowi „zsocjologizować” jego podejście do nauki prawa, a także wprowadzić do rozważań - w celach polemicznych wobec dorobku autora Gospodarki $i$ społeczeństwa - elementy pochodzace ze zdecydowanie nietypowego jak na standardy prawnicze obszaru teologii. Dla naszych rozważań kluczowe jest jednak to, czy i jak Schmitt ustosunkował się do podanej przez Webera definicji państwa jako monopolu przemocy ${ }^{2}$. Za Weberem przyjmuje się, że to państwo ma monopol przemocy, a inne instytucje polityczne czy jednostki, sięgając po przemoc, czynia to $\mathrm{w}$ sposób niezgodny $z$ prawem. Nielegalne użycie przemocy jest obarczone sankcja prawna, gdyż stanowi zagrożenie dla obszaru skumulowanej władzy państwa. Monopol legalnej przemocy urasta $\mathrm{w}$ tym ujęciu do rangi specyficznego kryterium państwowości, które pozwala niejako odróżnić państwo od innego rodzaju form życia politycznego.

Problem tego, czym jest państwo, nie był Schmittowi obojętny. Już w jednej $z$ pierwszych swoich prac, powstałych w polemice do

\footnotetext{
2 „Przemoc nie jest naturalnie w żadnym razie normalnym czy jedynym środkiem państwa, $z$ pewnościa jednak swoistym dla niego. [...] W przeszłości najrozmaitsze związki - poczynając od rodu - posługiwały się fizyczna przemoca jako całkiem normalnym środkiem. Natomiast dziś stwierdzić musimy, że państwo jest tą ludzką wspólnota, która w ramach pewnego terytorium [...] pretenduje (skutecznie) do monopolu prawomocnego posługiwania się fizyczna przemoca. Albowiem dla współczesności charakterystyczne jest to, że wszelkim innym związkom i poszczególnym osobom przypisuje się prawo posługiwania się fizyczna przemoca tylko w tej mierze, w jakiej dopuszcza ja państwo: to ono uchodzi za źródło "prawa" stosowania przemocy”. M. Weber, Gospodarka i społeczeństwo. Zarys socjologii rozumiejacej, przekład D. Lachowska, Wydawnictwo Naukowe PWN, Warszawa 2002, s. 1023.
} 
klasycznego pozytywizmu prawnego, podją poszukiwania kryterium państwowości ${ }^{3}$. Co ciekawe, Schmitt nie uznaje tam przemocy za takie kryterium. Wyraża bardziej idealistyczny stosunek do obowiązującej teorii państwa i prawa, poszukując abstrakcyjnego elementu pierwotnego w stosunku do państwa, który pozwoliłby wypełnić przepaść między tym, co konkretne, a tym, co abstrakcyjne. Tym łącznikiem ma być bliżej nieokreślone, złożone $z$ ponadempirycznych norm, idealne prawo, które będzie pierwotne w stosunku do prawa państwowego ${ }^{4}$ W pismach Schmitta jest to bodaj jeden $z$ niewielu przykładów chęci znalezienia trzeciej drogi między pozytywizmem prawnym a jusnaturalizmem. Jednak te pierwsze próby poszukiwania specyficznych cech państwowości okazały się dla jurysty niesatysfakcjonujace, stąd też łatwo znaleźć ich kontynuację w kolejnych tekstach. Kwestia przemocy jako kryterium państwowości, wprawdzie odrzucona, znajduje się niejako w tle rozważań autora Teologii politycznej, zwłaszcza tam, gdzie rozwija on swoją teorię decyzjonizmu ${ }^{5}$.

Głównym argumentem niniejszego artykułu jest to, że Schmitt modyfikuje Weberowska koncepcje państwa jako monopolu przemocy. Istota suwerennej władzy w państwie nie sprowadza się, jego zdaniem, jedynie do monopolu (legalnego) stosowania przemocy. Dowartościowując myślenie instytucjonalne, traktował będzie państwo jako równoznaczne $z$ monopolem podejmowania ostatecznych decyzji. W artykule postaram się pokazać przekształcenie Weberowskiej koncepcji państwa jako monopolu przemocy w koncepcję państwa jako monopolu polityczności na przykładzie tekstów autora Pojęcia polityczności $\mathrm{z}$ lat dwudziestych i trzydziestych XX wieku.

\footnotetext{
3 C. Schmitt, Der Wert des Staates und die Bedeutung des Einzelnen, Duncker und Humblot, Berlin 2004 [I wyd. 1914]. Por. H. Hofmann, Legitimität gegen Legalität. Der Weg der politischen Philosophie Carl Schmitts, Duncker und Humblot, Berlin 2010, s. 17

${ }_{4}$ C. Schmitt, Der Wert des Staates..., s. 77. Por. nt. braku spójności Schmitta w tej kwestii G. Balakrishnan, The Enemy. An Intellectual Portrait of Carl Schmitt, Verso, London - New York 2000, s. 15.

5 Zob. Ł. Święcicki, Decyzjonizm jako doktryna antypozytywistyczna. Zarys myśli prawno-politycznej Carla Schmitta w latach 1912-1928, „Pro Fide Rege et Lege” 2015, nr 2 (75-76), s. $246-274$.
} 
Jeśli chcielibyśmy wskazać dwa pojęcia, które wyznaczają niejako sens teorii Schmitta, pozwalają nam zorientować się w tym, co afirmuje, a co odrzuca, to byłyby to porzadek i chaos. Można powiedzieć, że jego cała refleksja o państwie i prawie zorientowana jest na zachowanie porządku i uniknięcie chaosu. Wpisuje się $\mathrm{w}$ to kwestia przemocy, która przybiera postać nieuporządkowaną w sytuacji chaosu, uporządkowaną zaś w sytuacji panującego porządku. Mamy tu do czynienia ze swoista dialektyka porządku i chaosu, która określa sens istnienia państwa, będącego dla Schmitta pojęciem historycznym, typowym dla konkretnej epoki, która jest epoka nowożytna ${ }^{6}$. U zarania tej epoki myślenie polityczne zdeterminowały koncepcje umowy społecznej $z$ teoria Hobbesa na czele, w których celem państwa jest zapewnienie bezpieczeństwa obywatelom poprzez pozbawienie ich naturalnego prawa do samoobrony. Rezygnujacc $z$ przemocy i przenosząc prawo do niej na państwo, ludzie mogli zyskać cenne bezpieczeństwo.

Zdaniem Schmitta, państwo jest w tej epoce forma organizacji porządku politycznego taka jak polis była dla starożytności lub feudalizm dla średniowiecza. Oznacza to tyle, że państwo nie jest pojęciem ponadczasowym, a w sensie ontologicznym państwo zakłada istnienie polityczności (obecnej w pełni w stanie natury). Uprzedniość polityczności ma również dowodzić historyczności państwa. W klasycznej niemieckiej dziewiętnastowiecznej nauce prawa pojęcie tego, co polityczne, było utożsamiane $z$ tym,

\footnotetext{
6 C. Schmitt, Nauka o konstytucji, przekład M. Kurkowska, R. Marszałek, Teologia Polityczna, Warszawa 2013, s. 18-19; idem, Pojęcie polityczności, w: idem, Teologia polityczna i inne pisma, przekład M. Cichocki, Wydawnictwo Aletheia, Warszawa 2012, s. 249-253, 275-278; idem, Epoka neutralizacji i apolityzacji, przekład W. Kunicki, w: W. Kunicki (red.), Rewolucja konserwatywna w Niemczech 1918-1933, Wydawnictwo Poznańskie, Poznań 1999, s. 435 i nast.; idem, Staat als ein konkreter, an eine geschichtliche Epoche gebundener Begriff (1941), w: idem, Verfassungsrechtliche Aufsätze aus den Jahren 1924-1954, Duncker und Humblot, Berlin 1957, s. 375-385.
} 
co państwowe (Georg Jellinek). Schmitt, poszukujac kryterium państwowości, odwraca perspektywę, czyniąc $z$ państwa jedynie epifenomen polityczności.

W ocenie Schmitta (podobnie jak u Thomasa Hobbesa) miejsce polityczności ${ }^{7}$ znajduje się przede wszystkim w stosunkach między narodami, gdyż jest to świat politycznego pluriversum, a nie universum. Jest to zupełnie normalne ${ }^{8}$, a wszelkie próby zniesienia polityczności w przestrzeni międzynarodowej postrzega Schmitt w sensie politycznym i metafizycznym jako znamiona końca pewnej epoki, a może nawet końca czasów: „Polityczna jedność - pisze - nie może obejmować całej kuli ziemskiej ani całej ludzkości"9. Jurysta chce dać stanowczy (polityczny i teoretyczny) odpór wierze, iż „wszystkie narody, religie, klasy społeczne i inne grupy ludzi na Ziemi połacza się w jedna całość”, wiara ta bowiem zakłada, że „zniknie różnica między przyjacielem a wrogiem nawet jako możliwość"10. Taki stan byłby zniesieniem polityczności w ogóle. To, co w stosunkach międzynarodowych Schmitt odrzuca, chce jednak widzieć w ramach państwa.

Wewnattrz państwa widzi Schmitt polityczność nie tyle znacząco ograniczoną, ile nawet na swój sposób zniesioną, ponieważ „każda teoria państwa jest pluralistyczna, ale nie w sensie wewnątrzpaństwowego pluralizmu"11. Wewnatrzpaństwowy pluralizm to stan walki wszystkich ze wszystkimi, w którym wiele partii uzurpuje sobie znajomość absolutnej prawdy w wymiarze państwowym, to jest definicji podstawy porządku i bezpieczeństwa. Nie oznacza to

\footnotetext{
7 „Specyficzne polityczne rozróżnienie, do którego można sprowadzić wszystkie polityczne działania i motywy, to rozróżnienie przyjaciela i wroga”. C. Schmitt, Pojęcie polityczności, s. 254.

8 Tezę o uniwersalności wyłącznie zewnętrznego charakteru polityczności popiera Schmitt przykładem $z$ Platona, u którego (w Państwie) różnica między wrogiem publicznym a prywatnym pozostaje $\mathrm{w}$ związku $\mathrm{z}$ przeciwieństwem między polemos a stasis, to jest między prawdziwą wojną a wojną domowa. „Za tym rozróżnieniem kryje się przekonanie - pisze Schmitt - że naród nie może toczyć wojny sam przeciwko sobie, a "wojna domowa" jest czymś w rodzaju samounicestwienia [...]”. C. Schmitt, Pojęcie polityczności, s. 256.

9 Ibidem, s. 285.

${ }^{10}$ Ibidem.

${ }^{11}$ Ibidem.
} 
braku wielości opinii czy istnienia wielu organizacji, instytucji czy partii w ramach jednego państwa. Kluczowym dopełnieniem tego pojęcia (czyli wewnattrzpaństwowego pluralizmu) jest owo nieuprawnione roszczenie jednej grupy do posiadania jedynej veritas. Oznacza to tyle, że dana grupa, mówiąc językiem Webera, daży do zdobycia władzy oraz, co sugeruje Schmitt, jej trwałego utrzymania na drodze zmiany konstytucji. Ideologicznie przekonana o swej racji grupa ta nie chce funkcjonować w ramach istniejącego porządku, lecz dąży do jego przekształcenia. W sensie praktycznym Schmitt postrzega takie dążenie jako zapowiedź wojny domowej. Można powiedzieć, że zło, które Hobbes widział $\mathrm{w}$ politycznym sekciarstwie, Schmitt dostrzega w rosnacych w siłę ideologiach XX wieku.

Powstanie państwa zrywa $z$ politycznościa stanu natury. Ponieważ zagrożenie wojna domowa jest największym niebezpieczeństwem dla istnienia państwa, polityczność - stan walki grup, nad którymi nie ma rozstrzygającego konflikt suwerena - oznacza $\mathrm{w}$ ramach państwa de facto jego koniec. Tak jak u Webera państwo posiadało monopol przemocy, by skorzystać $z$ niego $\mathrm{w}$ razie konieczności, tak u Schmitta państwo (suweren) ma monopol polityczności, by w razie konieczności podjąć w najwyższym stopniu polityczną decyzję o być albo nie być państwa. Zarówno w pierwszym, jak i w drugim przypadku monopol przemocy/polityczności oznacza, że nikt inny prócz państwa/suwerena nie jest uprawniony do przemocy/polityczności. Jeśli ktoś odwołuje się do przemocy/polityczności w sposób nieuprawniony, zachwiany zostaje porzadek państwowy. Państwo traci ów monopol i powracamy do stanu chaosu. Monopol przemocy lub polityczności zakłada, że polityczności, jak i przemocy nie da się wyeliminować $z$ życia społecznego. Istnieje zawsze możliwość nieuprawnionego pojawienia się polityczności. Grupa lub partia, która staje w opozycji do istniejącego porządku, otwiera możliwość wewnętrznej polityczności, kwestionując tym samym monopol państwa. 


\section{II}

Myśl polityczna Schmitta wynika ze świadomości kryzysu państwa, który polega w swej istocie na utracie istniejaccego od XVI wieku monopolu polityczności. Jeszcze w XVIII stuleciu, twierdzi Schmitt, państwo górowało nad społeczeństwem, sprawując nad nim stabilna i niepodzielna władzę. Takie państwo to już jednak historia. W wieku XX „państwo i społeczeństwo przenikają się wzajemnie”, tak że „wszystkie dotąd wyłącznie społeczne problemy nabieraja państwowego znaczenia"12. Państwo jest odtąd państwem totalnym, to jest tożsamym ze społeczeństwem. Stanowi tym samym przeciwieństwo powstałego na początku nowożytności, w założeniu korzystnego dla życia i przetrwania ludzi, zjawiska neutralizacji i odpolitycznienia obszarów życia: nie ma więcej neutralnych (niepaństwowych i niepolitycznych) obszarów, wszystko jest „przynajmniej potencjalnie polityczne” ${ }^{13}$. Życie społeczne ulega polityzacji pierwotnie zarezerwowanej dla stosunków między państwami: polityczność naturalnie cechująca relacje między państwami opisuje teraz stosunki polityczne $\mathrm{w}$ ramach państwa. W ten sposób wszystko staje się w najwyższym stopniu polityczne, dlatego możemy mówić o totalizacji polityczności wewnatrz państwa. Totalizacja ta wynika ze słabości państwa, w jaka popadło za sprawa neutralizacji.

Wiek XX to dla Schmitta kolejny etap rozłożonego na cztery stulecia procesu neutralizacji i depolityzacji, który decyduje o podstawie istnienia państwa. W następnych epokach bowiem zmieniają się obszary centralne, będące politycznym obszarem neutralnym, od teologii i metafizyki przez moralność do ekonomii i techniki. Początek procesu jest tożsamy $z$ narodzinami państwa, gdy w XVI stuleciu po wojnach domowych „mieszkańcy Europy poszukiwali neutralnego obszaru, w którym ucichłyby spory

12 Ibidem, s. 249.

${ }^{13}$ Ibidem, s. 250. 
i gdzie można by się było porozumieć, pogodzić i nawzajem przekonać"14. Wykształcenie się neutralnego obszaru centralnego pozwoliło zakończyć dysputy i spory teologiczne, stworzyć państwo na nowych fundamentach. Nowożytne państwo „czerpie swa rzeczywistość i moc $z$ właściwego mu każdorazowo obszaru centralnego"15. W XIX wieku doszło, zdaniem Schmitta, do specyficznej, bo połączonej $z$ daleko idacca depolityzacja, neutralizacji. Obecnie jednak epoka techniczności tworzy złudzenie, jakoby nie istniało w rzeczywistości nic bardziej neutralnego od niej, idzie za tym daleko idaca obietnica ostatecznego rozwiąania wszelkich sporów politycznych. Efektem neutralizacji typowej dla epoki techniczności jest tak zwane agnostyczne państwo liberalne ${ }^{16}$.

Czym jest państwo neutralne? Neutralność państwa w koncepcji Schmitta nie oznacza neutralności w stosunkach zewnętrznych, jaka znamy w przypadku choćby wiecznej neutralności Szwajcarii. Neutralność w teorii autora Teologii politycznej odnosi się do wewnatrzpolitycznego stanu, jaki jest, jego zdaniem, udziałem współczesnego państwa. Jest to stan etycznej neutralności, w którym państwo przestało być instancją najwyższą, miarodajnym sędzią; teraz każdy - niczym w stanie natury - jest sędzią we własnej sprawie, państwo nie rozstrzyga o dobru i złu, o tym, co dla niego korzystne lub nie ${ }^{17}$. Państwo neutralne to państwo, które „zostaje sprowadzone do poziomu jednego $z$ wielu społecznych zwiąków i stowarzyszeń, które istnieje obok innych, ale nigdy ponad nimi"18. Człowiek w pluralistycznym społeczeństwie odnajduje się przede wszystkim jako członek różnych wspólnot, związków i instytucji niepaństwowych, które go zobowiązuja do wierności. Lojalność wobec państwa nie różni się w tym układzie niczym

\footnotetext{
${ }^{14}$ C. Schmitt, Epoka neutralizacji..., s. 437.

${ }^{15}$ Ibidem, s. 435.

${ }^{16}$ Krytyka liberalnego państwa prawa wynika u Schmitta, jak widzimy, z jego krytyki rzeczywistości. Por. Ł. Święcicki, Krytyka nierzeczywistości w konserwatyzmie Carla Schmitta i Leo Straussa, „Studia nad Autorytaryzmem i Totalitaryzmem” 2015, z. 37, nr 2, s. 32-39.

${ }^{17}$ C. Schmitt, Etyka państwowa a pluralistyczna teoria państwa (1930), w: idem, Teologia polityczna..., s. 228.

${ }^{18}$ Ibidem, s. 229.
} 
od lojalności wobec podmiotów niepaństwowych; jest jednym $z$ wielu równych sobie zobowiązań przyjętych przez autonomiczna jednostkę. Mamy zatem do czynienia $z$ "politeizmem” instytucji, w którym dokonała się dekapitacja „monoteistycznej” głowy państwa. Owo zrównanie państwa $z$ instytucjami niepaństwowymi jest dla Schmitta podstawowym wymiarem problemu neutralności państwa. Zrelatywizowane, politycznie „zdekapitowane” państwo jest w najlepszym razie jedynie „neutralnym mediatorem”, „rozjemca stroniącym od jakiejkolwiek autorytatywnej decyzji”" ${ }^{19}$. Państwo nie jest już w stanie „zapanować nad społecznymi, ekonomicznymi lub religijnymi sprzecznościami”, a „wręcz je ignoruje i oficjalnie w ogóle nic o nich nie chce wiedzieć" 20 . Świadczy to o głębokim kryzysie nowożytnego państwa, które Schmitt odtąd chce nazywać państwem pasywnym czy państwem agnostycznym ${ }^{21}$. Agnostycyzm państwa oznacza tu nic innego jak stan oficjalnie deklarowanej niewiedzy o tlących się konfliktach wewnątrzpolitycznych, z którego wynika stan praktycznej obojętności i bierności państwa wobec stron pozostających w układzie przyjaciel-wróg.

Źródła państwa neutralnego widzi Schmitt nie w przemianach społecznych, lecz w zmianach, używając jego określenia, duchowo-historycznych, które dokonały się w nauce prawa ostatniego stulecia. Widać tu ciagłość Schmittowskiej metody, zakładającej „istnienie zgodności teologicznego i metafizycznego obrazu świata z obrazem państwa"22. Krytykowana przez Schmitta neutralność państwa wzięła się $z$ błędnych teorii państwa, które doprowadziły do jego kryzysu. W Pojęciu polityczności Schmitt zawarł przestrogę przed, jego zdaniem, fatalnymi skutkami wpływu myśli liberalno-pozytywistycznej na naukę prawa. Myśl ta, będac w gruncie rzeczy - choć próbuje się temu zaprzeczyć - metafizycznym systemem, związana jest ściśle $z$ ideami pluralizmu, neutralności

\footnotetext{
${ }^{19}$ Ibidem, s. 231.

${ }^{20}$ Ibidem.

${ }^{21}$ C. Schmitt, Hugo Preuss. Sein Staatsbegriff und seine Stellung in der deutschen Staatslehre, J.C.B. Mohr, Tübingen 1930, s. 24.

${ }^{22}$ Idem, Etyka państwowa a pluralistyczna..., s. 230.
} 
i antypolityczności ${ }^{23}$. Wszystko to stanowi dla Schmitta podstawy myślenia nienaukowego, ideologicznego, które nie powinno mieć miejsca $\mathrm{w}$ prawie. Nie postrzega się bowiem rzeczy takimi, jakimi są, uwzględniając dokonujące się zmiany, lecz narzuca się rzeczywistości odgórnie wypracowane koncepcje prawno-polityczne. Można odnieść wrażenie, że opisane przez Schmitta procesy, które legły u przyczyn kryzysu państwa, dotyczą także, a może przede wszystkim, nauki prawa. Wychodzac naprzeciw temu fatalnemu w skutkach myśleniu, jurysta proponuje postrzeganie problemów prawnych w sposób realistyczny ${ }^{24}$.

Realistyczne myślenie polega na tym, by konfrontować zastana rzeczywistość z ideami prawnymi i politycznymi. Schmitt nie zaproponował nigdy definicji państwa, która nie uwzględniałaby populacji zamieszkującej dane terytorium. Co więcej, ponieważ jego myśl jest polityczna, wychodzi on - pod wpływem dynamicznego charakteru decyzjonizmu - daleko poza statyczność Jellinkowej definicji, by określić państwo przez wzgląd na status polityczny konkretnego narodu. Warunkiem trwania tego statusu jest jedność polityczna.

Państwo nowoczesne jest integralna jednościa polityczną i w swej istocie statusem par excellence, tzn. statusem totalnym, który relatywizuje $\mathrm{w}$ sobie samym każdy inny status. Nie może ono w sobie samym [to jest $\mathrm{w}$ obszarze swojej władzy określonym istnieniem drugiego państwa]

\footnotetext{
${ }^{23}$ Słusznie zauważył George Schwab (The Challenge of Exception. An Introduction to the Political Ideas of Carl Schmitt between 1921 and 1936, Duncker und Humblot, Berlin 1970, s. 59), że krytyka pluralizmu jest $w$ pismach Schmitta wycelowana $z$ imienia w koncepcje Laskiego, Cole'a, a nie Kelsena, ale Schmittowi chodziło nie tyle o poglady tych anglosaskich myślicieli, ile o ogólna krytykę poglądów negujących nadrzędność państwa (czy to nad społeczeństwem, czy to nad porządkiem prawnym). Przez pojęcie „antypolityczności” rozumiem nie przeciwieństwo polityczności, lecz stanowisko apolityczne, które dąży do ograniczenia lub likwidacji polityczności.

${ }^{24}$ Renato Cristi twierdzi, że między Teologia polityczna a Nauka o konstytucji występuje różnica stanowiska w kwestii podmiotu suwerenności, którym w pierwszym przypadku jest monarcha, a w drugim naród (w sensie politycznym). Teza ta jest jednak oparta na błędnym założeniu, jakoby Teologia polityczna utożsamiała suwerenność $z$ „zasadą monarchiczna”. W świetle czwartego rozdziału tej pracy Schmitta oraz jego dzieła o dyktaturze oczywiste jest, że Schmitt był w pełni świadom, iż monarchia należy do przeszłości. Por. R. Cristi, Carl Schmitt on Sovereignty and Constituent Power, w: D. Dyzenhaus (red.), Law as Politics. Carl Schmitt's Critique of Liberalism, Duke University Press, Durham - London 1998, s. 179-192.
} 
uznać żadnego danego przed państwem lub poza państwem równouprawnionego publicznego statusu prawnego, podobnie jak członów pośrednich, które - gdy znajduja się poza nim lub okazują się samodzielne obok niego - wkraczałyby w jego sferę ${ }^{25}$.

Istotą politycznej egzystencji jedności politycznej jest możliwość dokonywania samodzielnego odróżniania przyjaciela od wroga. Naród (jedność polityczna), który zrezygnuje $z$ polityczności, naiwnie wierzac w jakieś utopie, nie zniesie samej polityczności, lecz w istocie straci ja na rzecz innego podmiotu, to jest najpewniej na rzecz innego państwa ${ }^{26}$. Rezygnacja $z$ decyzji politycznej oznacza więc koniec istnienia politycznej jedności. Jedność polityczna traktuje Schmitt jako niemal tożsama $z$ państwem, gdyż państwo jest dla niego „określonym statusem narodu, statusem jedności politycznej"27. Dlatego można powiedzieć, że do istoty państwa należy zdolność i możliwość dokonywania samodzielnego, suwerennego odróżnienia przyjaciela od wroga, bez której to zdolności państwo nie może istnieć. Państwo traktuje więc Schmitt nie w sposób abstrakcyjno-formalny, lecz konkretny i egzystencjalny, gdyż ściśle związany $z$ istnieniem jedności politycznej. Warunkiem istnienia państwa jest utrzymanie jedności politycznej. Nie skłania się zatem Schmitt do idei państwa jako wiecznego i ponadczasowego bytu, który należałby do jakiegoś procesu historii. To jedność polityczna okazuje się historycznie poprzedzać pojęcie państwa. Państwo jest dla niego pojęciem historycznym, typowym dla epoki nowożytnej; jest ono także niejako organizmem, który przetrwa, jeśli nie doświadcza go śmiertelnie groźne „choroby”.

Najgroźniejsza „chorobą" państwa jest jego niezdolność do podejmowania decyzji politycznej w sprawie tego, kto jest wrogiem, a kto przyjacielem, która to decyzja określa status jedności politycznej. Niezdolność ta wynika $z$ teorii neutralności państwa postulowa-

\footnotetext{
${ }^{25}$ C. Schmitt, Nauka o konstytucji, s. 290 (kursywa C.S.).

${ }^{26}$ Idem, Pojęcie polityczności s. 280-281.

${ }^{27}$ Idem, Nauka o konstytucji, s. 332. Według Schmitta, „lud istniejacy jako jedność polityczna ma byt wyższego rodzaju, spotęgowany i intensywniejszy, w porównaniu $z$ bytowaniem naturalnym grupy ludzi jakoś współistniejących”. Ibidem, s. 339.
} 
nej przez liberalizm. Obszary neutralne, które ludzie odnajdywali w różnych dziedzinach w ciagu wieków, miały służyć porozumieniu, lecz zawsze istniała możliwość zaprzepaszczenia ich dobrej woli. Inaczej mówiąc, widmo wojny zawsze istniało na horyzoncie porozumienia. Współczesna epoka jest w tym sensie zupełnie inna od poprzednich. Nowy rodzaj neutralizacji zakłada bowiem zniesienie polityczności w ogóle. Negatywny stosunek liberalizmu do polityczności przypomina dominujące w nauce prawa „przekonanie, że ekstremalna, wyjątkowa sytuacja może kiedyś zniknąć z ludzkiego życia"28: stanowisko antypolityczne jest bowiem podobne - polityczność zniknie kiedyś z ludzkiego życia. W prawie pogląd ten znajduje, zdaniem Schmitta, odzwierciedlenie w opinii, że polityczność, podobnie jak wyjątek, „na pewno nie jest kwestia, która podlegałaby spekulacjom prawnym"29.

Schmitt okazuje się teoretykiem walczącym o prawomocność polityczności w nauce i praktyce politycznej, a właściwie o uznanie jej koniecznej obecności i zaprzestanie antypolitycznej walki. Argument Schmitta opiera się, przynajmniej do pewnego momentu, na przekonaniu, że miejsce polityczności jest równie zasadne i usprawiedliwione w życiu społecznym jak obecność innych dziedzin aktywności ludzkiej. Inaczej będzie twierdził po 1933 roku, gdy jego koncepcja ulegnie intensyfikacji politycznej.

Zawarty w Pojęciu polityczności problem przynależności danych dziedzin życia lub określonych zjawisk do sfery życia politycznego rozwija Schmitt, nadając kontekst prawno-konstytucyjny, w Problemie wewnatrzpolitycznej neutralności państwa $(1930)^{30}$. Tytułowy problem dotyczy niemal wszystkich różnych od siebie obszarów, takich jak religia, światopogląd, nauka, kultura itp. Językiem dominujacym w przedstawionej przez Schmitta sytuacji historycznej jest język ekonomii, która wyznacza - razem $z$ technika - aktualny obszar centralny. Dlatego gospodarka jest najlepszym przykładem

\footnotetext{
${ }^{28}$ C. Schmitt, Teologia polityczna, s. 47.

${ }^{29}$ Ibidem.

${ }^{30}$ C. Schmitt, Das Problem der innerpolitischen Neutralität des Staates (1930), w: idem, Verfassungsrechtliche Aufsätze..., s. 41-59.
} 
do wyjaśnienia ogólnego problemu. Współczesne państwo bowiem, twierdzi Schmitt, jest państwem ekonomicznym (Wirtschaftsstaat). Wobec ekonomii konstytucja państwa jest neutralna, ale ekonomia nie jest neutralna wobec państwa. Schmitt sprzeciwia się tym samym podporządkowaniu języka prawniczego językowi ekonomii ${ }^{31}$. Szczególnie dotyczy to problemu neutralności.

Liberalna koncepcja państwa ${ }^{32}$ zakłada jego neutralny stosunek do takich obszarów życia jak gospodarka, religia, nauka, sztuka czy kultura. W praktycznym sensie polega ona na niemieszaniu się lub nieinterweniowaniu państwa w te obszary. Myślenie ekonomiczne, któremu sprzyja liberalizm, chętnie zamieniłoby obywatela w producenta ${ }^{33}$. Zdaniem Schmitta, ustrój gospodarczy nie może decydować o ustroju politycznym. Nie chodzi tu o abstrakcyjne dywagacje o dwóch niepasujacych do siebie systemach lub formach organizacji porządku politycznego. Jurysta wychodzi z praktycznego punktu widzenia: „Masy współczesnych wyborców będa prawdopodobnie zawsze grupować się według interesów gospodarczych i nie da się tego zmienić żadna ustawą" ${ }^{34}$. Dostosowanie ustroju politycznego do oczekiwań owych masowych zgrupowań ludzkich „nie wzmocni jedności woli państwowej, lecz jej zagrozi; gospodarcze i społeczne przeciwieństwa nie zostana rozwiąane i zniesione, lecz ukażą się otwarcie jeszcze bardziej bezwzględnie, ponieważ walczace grupy nie będą zobowiązane iść okrężna droga wyborów powszechnych i reprezentacji narodu"35. Ekonomizacja, o której pisze Schmitt, oznacza tu nic innego jak dostosowanie ustroju gospodarczego do wymogów konkretnej ideologii. Podporządkowanie polityki zideologizowanemu myśleniu ekonomicznemu ułatwia nie tylko zmianę ustroju gospodarczego, ale również politycznego. Ekonomia, jak wiemy, nie jest dla Schmitta zupełnie

\footnotetext{
${ }^{31}$ Idem, Epoka neutralizacji..., s. 436.

${ }^{32} \mathrm{~W}$ innym tekście $z$ tego samego okresu pisał Schmitt, że „Wyobrażenie wewnatrzpolitycznie neutralnego państwa jest typowym wyobrażeniem liberalnym". C. Schmitt, Hugo Preuss..., s. 19.

${ }_{33}^{33}$ Por. Idem, Das Problem der innerpolitischen..., s. 42.

${ }^{34}$ Ibidem, s. 44.

${ }^{35}$ Ibidem.
} 
neutralna, dlatego jakakolwiek decyzja w sprawie ustroju gospodarczego będzie zbliżać lub oddalać od zarysowanej przez niego alternatywy między systemem komunistycznej Rosji a systemem faszystowskich Włoch ${ }^{36}$. Trzeba pamiętać, że gospodarka czy ekonomia to $u$ Schmitta pojęcia znacznie szersze niż to, co dziśs przez nie rozumiemy. Termin Wirtschaft jest niemal tożsamy $z$ organizacją spraw wewnętrznych, działalności międzyludzkiej w sensie Weberowskim. Potwierdza to zdanie jurysty: „System ustroju zorientowanego gospodarczo nie ma w żadnym wypadku na celu, by uczynić gospodarkę [Wirtschaft] wolną i autonomiczna, lecz - przeciwnie - by oddać ja w ręce państwa i jemu ja podporządkować"37.

Schmitt dopuszcza możliwość, by zasada nieinterwencji państwa obowiązywała w tych przypadkach, gdzie państwo - na drodze sądowej - rozstrzyga spory i konflikty między interesariuszami w sprawach dotyczacych gospodarki. W sporach tych państwo nie jest strona, lecz arbitrem, neutralnym i obiektywnym podmiotem. Jeśli jednak idzie o sprawy państwowe i polityczne, takie ujęcie roli państwa musi prowadzić do niezdecydowania (Nicht-Entscheidung), państwo bowiem albo będzie stroną sporu, a przez to nie pozostanie neutralne, albo nie będzie strona, a zatem zabraknie mu znajomości rzeczy ${ }^{38}$. Okazuje się, że groźba upolitycznienia (w znaczeniu upartyjnienia) jest zbyt duża, by państwo mogło zachować neutralna pozycję. Brakuje decyzji, która rozstrzygałaby ewentualne spory, nie będąc decyzja partyjna i nierzeczowa.

\footnotetext{
${ }^{36}$ Schmitt kreśli wyraźną alternatywę (w sensie wyboru politycznego) między faszystowskimi a marksistowskimi rozwiąaniami, a nie między faszyzmem a demokracja. Podobieństwo między nimi polega, po pierwsze, na sprzeciwie wobec liberalizmu, którego jurysta, wbrew dominującej opinii, nie łączy z demokracja, po drugie, na podporządkowaniu myślenia politycznego myśleniu ekonomicznemu. W tym sensie oba sa rewolucyjne i antypolityczne. Zob. C. Schmitt, Wesen und Werden des faschistischen Staates (1929), w: idem, Positionen und Begriffe im Kampf mit Weimar-Genf-Versailles 1923-1939, Duncker und Humblot, Berlin 1994, s. 125-128; idem, Der unbekannte Donoso Cortés, w: idem, Positionen und Begriffe..., s. 134.

${ }^{37}$ Idem, Das Problem der innerpolitischen..., s. 44-45.

${ }^{38}$ Ibidem, s. 51.
} 


\section{III}

W Problemie wewnątrzpolitycznej neutralności państwa Schmitt poddaje krytyce sytuację współczesnych Niemiec, którą po raz pierwszy określa za pomoca terminu państwa partyjnego. Państwo, twierdzi, zmieniło się w „państwo zmiennej koalicji partyjnej” (labiler Koalitions-Parteien-Staat), w którym wola państwa kształtuje się zależnie od „zmiennych, zmieniających się od przypadku do przypadku większości parlamentarnych”39. W ten sposób „substancja polityczna” przeszła do pomniejszych podmiotów systemu politycznego, które przejęły rolę państwa. Państwo zmiennych koalicji partyjnych jest pozbawione wyłączności na polityczność i dlatego nazywa je Schmitt „państwem wewnątrzpolitycznie neutralnym”40. Jest to państwo, w którym pluralizm okazał się tak silny, że właściwie rządzą w nim wszelkie umowy i porozumienia. Jedność polityczna zostaje zastapiona przez "system wewnątrzpaństwowych porozumień" między państwem a landami, państwem a społecznościami wyznaniowymi ${ }^{41}$. System ten jest wyrazem pluralizmu, który rozwija się dzięki procesom depolityzacji i neutralizacji.

Państwo zmiennej koalicji partyjnej okazuje się w coraz mniejszym stopniu państwem, gdy staje się polem walki rozmaitych grup politycznych. Wewnattrzpaństwowe porozumienia, kompromisy czy umowy to dla Schmitta dowód tego, że państwo jest przedmiotem handlu: „Biorace udział w koalicji partie dziela się wpływami i urzędami państwowymi według ustawowej kwoty"; podział ten nazywa Schmitt parytetem, który dla partii jest miarą sprawiedliwości ${ }^{42}$. Konstytucja pluralistycznego państwa jest ograniczona do zasady dotrzymywania umów (pacta sunt servanda) oraz ochrony uzyskanych przywilejów ${ }^{43}$.

\footnotetext{
${ }^{39}$ Ibidem, s. 45.

40 Ibidem, s. 47.

${ }^{41}$ Ibidem, s. 54.

${ }^{42}$ Ibidem, s. 55.

${ }^{43}$ Por. C. Schmitt, Etyka państwowa..., s. 244.
} 
Wewnętrzny pluralizm wpływa na funkcjonowanie państwa, które staje się polem walki interesów partyjnych. Schmitt łączy swoja krytyke parlamentaryzmu, diagnozę społeczeństwa masowego, kryzysu państwa $z$ krytyka wpływów liberalizmu w nauce prawa. Parlament jest odzwierciedleniem pluralistycznych sił występujących w państwie, a ponieważ państwo jest tożsame ze społeczeństwem, czyli $z$ tym, co do niedawna postrzegano jako niepaństwowe, może Schmitt mówić o państwie partyjnym ${ }^{44}$.

Kontynuację rozważań na temat kryzysu państwa jako kryzysu monopolu polityczności znajdziemy w niedocenianym dziele Legalność i prawomocność z 1932 roku, którego tytuł nawiąuje wprost do pojęć stosowanych przez Maksa Webera. Praca Schmitta ma szczególne znaczenie, gdyż, jak wyraziła to Ellen Kennedy, w niej jurysta przewidział koniec Weimaru ${ }^{45}$.

Objawem kryzysu państwa jest istnienie państwa prawa w postaci państwa ustawodawczego (Gesetzgebungsstaat), które charakteryzuje się nie tylko dominująca pozycją legislatywy, ale także wykluczeniem $z$ ustroju realnej władzy (jako autorytetu) czy zwierzchności. Rządzą bowiem w takim państwie, a właściwie obowiązują w nim, ustawy (normy). W takim państwie, pisze Schmitt, „władzy i nagiej siły już po prostu nie ma"46. Oznacza to tyle, że władza realizuje się tylko „na podstawie ustawy” lub „w imieniu ustawy"47. Ma ona charakter bezosobowy: władza sprowadza się do obowiązywania prawa, a nie do arbitralnych rozstrzygnięć.

Kryzys państwa Schmitt wyraźnie wiąże $z$ oddziaływaniem normatywizmu $\mathrm{w}$ prawie, który opiera myślenie prawnicze na pojęciu legalności. Dominacja myślenia w kategoriach legalności znamionuje jego zdaniem przejście od prawomocności do legalności,

\footnotetext{
${ }_{44}^{44}$ Por. idem, Die Wendung zum totalen Staat, w: idem, Positionen und Begriffe..., s. 176.

${ }^{45}$ E. Kennedy, Constitutional Failure: Carl Schmitt in Weimar, Duke University Press, Durham - London 2004, s. 20. Zdaniem Reinharda Mehringa (Carl Schmitt zur Einführung, Junis, Hamburg 2001, s. 55), możliwość końca Republiki Weimarskiej była według Schmitta założona w konstytucji za sprawą wewnętrznej sprzeczności, jaką oznacza połączenie liberalizmu $z$ demokracją.

${ }^{46}$ C. Schmitt, Legalität und Legitimität, Duncker und Humblot, Berlin 2005 [1932], s. 8.

${ }^{47}$ Ibidem.
} 
od legitymacji dawnego typu, odwołującej się do boskiego pochodzenia władzy, do prawomocności wynikającej z czystej legalności jako zgodności działań z ustawą. Schmitt jest tak radykalny w swej krytyce, że decyduje się odmówić państwu ustawodawczemu, czyli Weimarowi, miana państwa prawa ${ }^{48}$. Prawo bowiem w tym typie państwa może być tak dowolne, że trudno, jego zdaniem, mówić, by miało ono coś wspólnego $z$ tymi cechami, jakie przypisuje się państwu prawa. Pojęcie państwa prawa stało się, jak twierdzi, orężem walki politycznej, w której wszelkich krytyków państwa ustawodawczego określa się jako przeciwników państwa prawa ${ }^{49}$.

Normatywizm okazuje się w perspektywie Schmitta nie dopełnieniem procesu przejścia od wertykalnej do horyzontalnej legitymacji władzy, czyli od monarchii do demokracji, lecz oparciem jej w istocie, w sensie egzystencjalnym, na niczym, to jest na ustawie, która jedna decyzja lub sytuacja wyjątkowa może zmienić, a więc na czymś niestabilnym. Schmitt poddaje tym samym krytyce roszczenie dominujacej doktryny prawa do, jej zdaniem jedynej zasadnej (wykluczającej rolę autorytetu), demokratycznej prawomocności.

W artykule o etyce państwowej pisał jurysta o tym, że państwo stało się neutralne, to znaczy niezdolne do podjęcia autorytatywnej decyzji, która rozstrzygnęłaby sprzeczności występujące w ramach państwa. Schmitt krytykuje państwo neutralne, gdyż w skrajnej formie, jako państwo totalne, czyli państwo, które jest tożsame ze społeczeństwem, a wszystko stało się polityczne, jest ono nie tylko „produktem równowagi między wieloma walczącymi grupami”, ale także „instancja, której celem jest zadbanie o równość zwalczajacych się stron"50. Właśnie problem równości stron wewnątrzpaństwowego konfliktu znajduje rozwinięcie w pracy z 1932 roku.

${ }^{48}$ Ibidem, s. 18.

49 Ibidem.

${ }^{50}$ C. Schmitt, Etyka państwowa..., s. 231. 
Rozwinięcie znajduje także zaznaczony w Strażniku konstytucji problem określenia zagrożenia. W 1930 roku pisał Schmitt, że kto jest strażnikiem, zależy od źródła pochodzenia zagrożenia. W 1932 roku zagrożenie nie jest już abstrakcyjnie ujęte jako parlament czy większość parlamentarna: chodzi wprost o otwarta droge legalnego przejęcia władzy przez najbardziej radykalne i rewolucyjne ruchy ${ }^{51}$.

W Legalności i prawomocności Schmitt rozwija wątek ledwie zaznaczony w tekście o wewnatrzpolitycznej neutralności państwa (przedrukowany zreszta w Strażniku konstytucji). Pisze ponownie o nowym pojęciu sprawiedliwości w pluralistycznym układzie sił wewnątrz państwa. O ile wcześniej zasada „sprawiedliwości” był w jego ocenie rodzaj parytetu, który przewidywał podział wpływów między partiami zasiadajacymi $\mathrm{w}$ parlamencie, o tyle teraz chodzi o zasadę równej szansy, która jest udziałem wszystkich bez wyjatku sił dażących do zdobycia władzy. To właśnie owa zasada równej szansy czy też równego dostępu do władzy staje się celem krytyki Schmitta wymierzonej w pozytywizm prawniczy. Zasada równej szansy wynika bowiem $z$ dominacji legalności w myśleniu prawniczym. Nie zakłada się, zdaniem Schmitta, że istnieje jakiś substancjalny porzadek odzwierciedlony $\mathrm{w}$ konstytucji weimarskiej, dlatego nie ma możliwości etyczno-politycznej oceny: państwo jest neutralne, czyli prawnie i politycznie obojętne.

Zasadniczy argument Legalności i prawomocności dotyczy konieczności powstrzymania partii napierających na osłabiony polityczna totalizacja ustrój państwa. Nie sa to bowiem zwykłe siły polityczne funkcjonujace $\mathrm{w}$ ramach porządku określonego $\mathrm{w}$ konstytucji, lecz siły o zintensyfikowanej polityczności, które przypisują sobie w nieuprawniony sposób ultima ratio, tak że zdobycie przez nie władzy (to jest większości w parlamencie) nie otworzy drogi do ustanowienia nowego rzadu, ale do zmiany ustroju. Intensyfikacja polityczna polega nie tylko na propagandowo wyrażanym nieuzasadnionym roszczeniu do władzy, ale również na oparciu

${ }^{51}$ Idem, Legalität und Legitimität, s. 14. 
swej polityki na pozapaństwowej sile przemocy. W Legalności i prawomocności Schmitt przywołuje ducha Webera nie tylko w tytule, ale również w kwestii monopolu państwowego: utrata monopolu przemocy, jeśli nie poprzedza utraty monopolu polityczności, to występuje równolegle.

Zastraszenie, manipulacja i propaganda moga umożliwić przejęcie władzy w państwie dlatego, że centrum władzy w konstytucji weimarskiej (zgodnie $z$ pozytywistyczno-liberalna interpretacja) znajduje się w parlamencie. W ten sposób mniejszość może legalnie, choć w czasach niespokojnych, zdobyć władzę nad większością. Rozważania Schmitta, jak sam pisze, motywowane są chęcia zapobieżenia tyranii większości, która jest bardziej realna niż kiedykolwiek, dzięki słabości tak zwanego państwa prawa ${ }^{52}$.

Przedstawiona przez Schmitta analiza prawno-politologiczna konstytucji weimarskiej okazała się prorocza. Można powiedzieć, że Schmitt przewidział możliwość legalnej rewolucji, która dokona się na drodze parlamentarnej. Niepowstrzymana przez nikogo większość parlamentarna, opierając się na ideologii i przekonaniu, że reprezentuje cały naród, zmieni - nie sięgając po narzędzia rewolucji i zamachu stanu - ustrój polityczny. W tej analizie rola przemocy nie jest pierwszorzędna. Kluczowa jest utrata przez państwo monopolu polityczności, zdolności do jasnego rozstrzygania o tym, kto jest wrogiem lub przyjacielem. Państwo przekształciło się za sprawa normatywizmu prawniczego w bezosobowe rzady ustawy, w których nie ma już władzy opartej na autorytecie tradycji czy konstytucji narodu. Niezdolność podjęcia arbitralnych decyzji o być albo nie być państwa otwiera możliwość w pełni legalnej zmiany ustroju przez zideologizowana mniejszość. Schmitt chce nam tym samym powiedzieć, że demokracji nie obroni się zasada rząów prawa, silnym parlamentem, lecz realna, osobowa,

52 Ibidem, s. 30-31. 
zdolna rozstrzygać w sytuacji egzystencjalnego zagrożenia państwa władza wybranego $\mathrm{w}$ powszechnych wyborach reprezentanta narodu (prezydenta). Tylko on może być prawdziwym strażnikiem konstytucji rozumianej jako coś więcej niż ustawa zasadnicza (norma podstawowa lub inaczej norma norm). Kwestia przemocy jest obecna w jego teorii niejako na drugim planie, ale można mieć wrażenie, że wcale nie zostaje zbagatelizowana. Posiadanie monopolu przemocy jest ściśle związane $z$ monopolem polityczności. Rezygnując $z$ obu, polityka nie wyzbywa się ich na zawsze. Przemocy i polityczności nie da się wyeliminować. Rezygnując z nich, państwo godzi się $z$ ich „proliferacja” wśród społeczeństwa. Dostając taka możliwość, zintensyfikowane politycznie grupy po przejęciu legalnie władzy zerwą raz na zawsze $z$ takim myśleniem, $z$ hukiem zamykajac za soba drzwi legalności.

Warto podkreślić jeszcze jedną rzecz. W sytuacji kryzysu Schmitt - konserwatywny katolik - opowiada się za demokracją przeciw prawniczemu legalizmowi. Wie bowiem, że w obliczu upadku tradycyjnych form legitymizacji władzy to demokracja - zgodnie $z$ obecnym duchem czasu - daje szansę na przeciwstawienie pustej legalności prawomocności rozstrzygnięć. 